\title{
PENYALURAN DANA PROGRAM KEMITRAAN DAN BINA LINGKUNGAN (PKBL) DAN KINERJA KEUANGAN BUMN \\ Rahmaditha Dewisari ${ }^{1}$ dan Roby Syaiful Ubed $^{2}$ \\ Politeknik Keuangan Negara STAN \\ E-mail : 4302180075_rahmaditha@pknstan.ac.id ${ }^{1}$ dan robyubed@pknstan.ac.id ${ }^{2}$
}

\section{INFORMASI ARTIKEL}

Diterima Pertama:

[30 Mei 2021]

\section{Dinyatakan Diterima:}

[26 Juni 2021]

Kata Kunci:

Kinerja perusahaan, Profitabilitas, Program Kemitraan dan Bina Lingkungan
ABSTRAK

This research was conducted using literature study method, utilizing data from financial statements and PKBL reports from 2015 to 2019 to figure the relation between a company's financial performance and its PKBL fund distribution. Measurement of financial performance is carried out on SOES whose business activities involve the use and/or management of natural resources, such as PT Brantas Abipraya, PT Jasa Marga, and PT Semen Indonesia, by calculating its profitability ratio in the form of return on asset. Based on the result, it is known that there is no relation between profitability ratio, precisely return on asset, and $P K B L$ fund distribution ratio. This shows that there is still room for improvement in the implementation of $P K B L$, in terms of regulation and implementation by the company itself, so that the benefits obtained from PKBL can be maximized. For further researchers, it is suggested to conduct research on more than 3 (three) research objects, and to also use other financial performance ratios and other variables that have not been used in this study.

Penelitian ini dilakukan dengan metode studi kepustakaan, menggunakan data sekunder yang bersumber dari laporan keuangan dan laporan PKBL perusahaan untuk mengetahui hubungan antara kinerja keuangan perusahaan dengan penyaluran dana PKBL tahun 2015-2019. Pengukuran kinerja keuangan perusahaan dilakukan pada BUMN yang kegiatan usahanya melibatkan penggunaan dan/atau pengelolaan SDA serta menyediakan informasi PKBL yang memadai, yaitu PT Brantas Abipraya, PT Jasa Marga, dan PT Semen Indonesia, menggunakan perhitungan rasio profitabilitas berupa return on asset. Berdasarkan hasil tinjauan, diketahui tidak terdapat hubungan antara rasio profitabilitas return on asset dengan rasio penyaluran dana program kemitraan dan bina lingkungan. Hal ini menunjukkan masih adanya ruang untuk pengembangan dalam penyelenggaraan PKBL, baik itu dari sisi kebijakan maupun dari pelaksanaan oleh perusahaan itu sendiri agar manfaat yang diperoleh dari PKBL dapat lebih maksimal. Bagi peneliti selanjutnya, disarankan agar dapat melakukan penelitian pada lebih dari 3 (tiga) perusahaan objek penelitian, serta turut menggunakan rasio kinerja keuangan atau variabel lainnya yang belum digunakan dalam penelitian ini. 


\section{PENDAHULUAN}

\subsection{Latar Belakang}

Gagasan tanggung jawab sosial perusahaan pada mulanya muncul dengan tujuan agar perusahaan dapat ikut serta menciptakan pembangunan yang berkelanjutan. Pelaksanaan tanggung jawab sosial di Indonesia bersifat wajib dan diselenggarakan dalam bentuk Tanggung Jawab Sosial dan Lingkungan (TJSL) bagi perseroan secara umum dan/atau Program Kemitraan dan Bina Lingkungan (PKBL) bagi BUMN. Kewajiban pelaksanaan PKBL bagi BUMN secara khusus disesuaikan dengan maksud dan tujuan pendirian BUMN yang tertuang dalam Undang-Undang Nomor 19 Tahun 2003 tentang Badan Usaha Milik Negara, yaitu turut aktif memberi bimbingan dan bantuan kepada pengusaha golongan ekonomi lemah, koperasi, dan masyarakat.

Agar tujuan akhir penyelenggaraan tanggung jawab sosial ini dapat tercapai, diperlukan dukungan dari pemerintah agar pelaksanaan TJSL dan PKBL dapat memberikan manfaat yang maksimal. Oleh karena itu, penelitian ini dilakukan untuk mengetahui hubungan antara kinerja keuangan BUMN dengan pelaksanaan program tanggung jawab sosial BUMN berupa Program Kemitraan dan Bina Lingkungan (PKBL) pada tahun 2015-2019. Penelitian dilakukan atas pelaksanaan PKBL yang dilakukan oleh PT Brantas Abipraya (Persero), PT Jasa Marga (Persero) Tbk, dan PT Semen Indonesia (Persero) Tbk.

\section{KERANGKA TEORI}

\subsection{Badan Usaha Milik Negara}

Badan Usaha Milik Negara (BUMN), menurut Undang-Undang Nomor 19 Tahun 2003 tentang Badan Usaha Milik Negara, didefinisikan sebagai badan usaha yang seluruh atau sebagian besar modalnya dimiliki oleh negara melalui penyertaan secara langsung yang berasal dari kekayaan negara yang dipisahkan. Sesuai tingkat kepemilikan sahamnya, BUMN terdiri atas dua bentuk, yaitu perusahaan perseroan (Persero), dan perusahaan umum (Perum).

Pendirian BUMN memiliki maksud dan tujuan untuk (a) memberikan sumbangan bagi perkembangan perekonomian nasional dan penerimaan negara; (b) mengejar keuntungan; (c) menyelenggarakan kemanfaatan umum berupa penyediaan barang dan/atau jasa yang bermutu tinggi dan memadai bagi pemenuhan hajat hidup orang banyak; (d) menjadi perintis kegiatan-kegiatan usaha yang belum dapat dilaksanakan oleh sektor swasta dan koperasi; (e) turut aktif memberikan bimbingan dan bantuan kepada pengusaha golongan ekonomi lemah, koperasi, dan masyarakat.
Sesuai dengan maksud dan tujuan turut aktif memberikan bimbingan dan bantuan kepada pengusaha golongan ekonomi lemah, koperasi, dan masyarakat, kemudian diterbitkan Peraturan Menteri Badan Usaha Milik Negara Nomor PER09/MBU/07/2015 tentang Program Kemitraan dan Program Bina Lingkungan Badan Usaha Milik Negara.

\subsection{Program Kemitraan dan Bina Lingkungan}

Program Kemitraan dan Bina Lingkungan (PKBL) terdiri atas dua jenis program, yaitu Program Kemitraan dan Program Bina Lingkungan.

Program Kemitraan adalah program untuk meningkatkan kemampuan usaha kecil agar menjadi tangguh dan mandiri. Pelaksanaan program kemitraan dilaksanakan dengan menyalurkan sejumlah dana dalam bentuk pinjaman untuk tujuan tertentu dan beban pembinaan kepada mitra binaan yang memenuhi syarat dan ketentuan tertentu sesuai isi Permen BUMN Nomor PER-09/MBU/07/2015 berikut peraturan-peraturan perubahannya.

Program Bina Lingkungan, atau Program BL, adalah program pemberdayaan kondisi sosial masyarakat oleh BUMN. Pelaksanaan program kemitraan dan program BL dikelola oleh Unit Program Kemitraan dan Program BL pada organisasi BUMN pembina selaku pelaksana Program Kemitraan dan/atau Program BL. Penyaluran dana program BL diberikan dalam bentuk bantuan untuk tujuan tertentu yang diatur dalam isi Permen BUMN Nomor PER09/MBU/07/2015 berikut peraturan-peraturan perubahannya.

Sumber dana program kemitraan dan program bina lingkungan yang diselenggarakan oleh BUMN diatur dalam Pasal 8 Permen BUMN nomor PER09/MBU/07/2015 tentang Program Kemitraan dan Program Bina Lingkungan Badan Usaha Milik Negara yang kemudian diubah dengan Permen BUMN nomor PER-03/MBU/12/2016, bersumber dari:

a. penyisihan sebagian laba bersih BUMN sebesar paling banyak 4\% (empat persen) dari proyeksi laba bersih tahun sebelumnya yang secara definitif ditetapkan pada saat pengesahan laporan tahunan, atau sebesar dana Program Kemitraan dan Program BL tahun sebelumnya apabila BUMN tidak memperoleh laba; dan/atau

b. anggaran yang diperhitungkan sebagai biaya pada BUMN

c. khusus untuk dana program kemitraan, dapat juga bersumber dari:

a) saldo dana program kemitraan yang teralokasi sampai dengan tahun 2015; 
b) jasa administrasi pinjaman/margin/bagi hasil, bunga deposito dan/atau jasa giro dari dana program kemitraan; dan/atau

c) pelimpahan dana program kemitraan dari BUMN lain, jika ada

d. khusus untuk dana program BL, dapat juga bersumber dari:

a) saldo dana program BL yang teralokasi sampai dengan akhir tahun 2015;

b) hasil bunga deposito; dan/atau

c) jasa giro dari dana program BL yang masih tersisa dari dana program BL tahun sebelumnya, jika ada

\subsection{Analisis Laporan Keuangan}

Analisis Laporan Keuangan dilakukan untuk mengetahui kinerja keuangan perusahaan yang dapat dilakukan dengan berbagai cara. Terdapat beberapa jenis teknik analisis laporan keuangan, salah satunya adalah dengan melakukan analisis rasio yang dapat digunakan untuk mengetahui hubungan antar pos dalam satu laporan keuangan atau hubungan pos-pos antara laporan keuangan neraca dan laporan laba rugi (Kasmir, 2013). Dengan kata lain, perhitungan rasio akan dilakukan dengan menggunakan data-data yang tersedia dalam laporan keuangan perusahaan yang selanjutnya diinterpretasikan untuk memenuhi tujuan perhitungannya.

Dalam penelitian ini, analisis kinerja keuangan dilakukan dengan menghitung rasio profitabilitas berupa return on asset perusahaan objek penulisan untuk selanjutnya ditinjau hubungannya dengan penyaluran dana program kemitraan dan bina lingkungan. Penggunaan return on asset diterapkan karena return on asset merupakan rasio yang mampu memetakan kemampuan perusahaan dalam menghasilkan laba bersih dari total aset yang dimanfaatkannya dalam kegiatan operasional (Purwanto, 2011).

Lebih lanjut, dijelaskan bahwa return on asset merupakan rasio yang mampu menunjukkan efisiensi dan efektivitas perusahaan dalam menggunakan asetaset yang dimilikinya untuk mendatangkan pendapatan bagi perusahaan.

Perhitungan return on asset diperoleh dengan menghitung hasil dari rumus berikut,

$$
\mathrm{ROA}=\frac{\text { Laba Bersih setelah Pajak }}{\text { Total Aktiva }} \times 100 \%
$$

Selanjutnya, analisis atas pelaksanaan program kemitraan dan bina lingkungan dilakukan dengan menghitung rasio penyaluran dana masingmasing program untuk menggambarkan perbandingan antara total dana yang tersedia untuk disalurkan dalam pelaksanaan PKBL pada tahun tertentu dengan laba bersih perusahaan pada periode pelaksanaan program. Besar Rasio Penyaluran Dana (RPD) dapat dihitung berdasarkan rumus:

$$
\mathrm{RPD}=\frac{\text { Total Dana yang disalurkan }}{\text { Laba Bersih }} \times 100 \%
$$

Penggunaan laba bersih dalam perhitungan rumus tersebut ditentukan berdasarkan ketentuan dalam Pasal 8 Permen BUMN nomor PER09/MBU/07/2015 yang kemudian diubah dengan Permen BUMN nomor PER-03/MBU/12/2016 yang menjelaskan sumber dana penyelenggaraan PKBL yang salah satunya dapat bersumber dari penyisihan sebagian laba bersih BUMN paling banyak sebesar $4 \%$ dari proyeksi laba bersih tahun sebelumnya.

\section{METODE PENELITIAN}

\section{Jenis Penelitian}

Jenis penelitian yang dilakukan dalam penelitian ini ialah penelitian deskriptif. Arikunto (2005, dikutip dalam Zellatifanny \& Mudjiyanto, 2018) menyatakan bahwa penelitian deskriptif merupakan jenis penelitian yang bertujuan untuk mengumpulkan informasi yang mampu menggambarkan keadaan tertentu dari objek penelitian, baik itu yang melibatkan adanya pengujian hipotesis maupun tanpa adanya pengujian hipotesis.

\section{Sumber data}

Data yang digunakan dalam penelitian ini adalah data sekunder yang berasal dari laporan keuangan dan laporan PKBL perusahaan yang dirilis pada tahun 2015 sampai dengan tahun 2019 di situs web perusahaan objek penelitian.

Perusahaan yang menjadi objek penelitian ialah perusahaan yang merupakan BUMN sehingga memiliki kewajiban menyelenggarakan PKBL, terutama perusahaan yang dalam menjalankan kegiatan usahanya melibatkan adanya penggunaan dan/atau pengelolaan sumber daya alam, serta perusahaan yang mencantumkan informasi penyelenggaraan PKBL dalam bentuk laporan PKBL secara lengkap pada tahun 2015 hingga tahun 2019. Perusahaan yang menjadi objek penelitian adalah PT Brantas Abipraya (Persero), PT Jasa Marga (Persero) Tbk, dan PT Semen Indonesia (Persero) Tbk.

\section{Teknik Analisis Data}

Penelitian dilakukan dengan menganalisis data sekunder yang disajikan dalam bentuk rasio keuangan dan rasio penyaluran dana PKBL untuk meninjau hubungan antara penyaluran dana PKBL dengan kinerja keuangan suatu perusahaan.

\section{HASIL PENELITIAN}

4.1. Kinerja Keuangan Perusahaan Objek

a. PT Brantas Abipraya (Persero) 
PT Brantas Abipraya pada tahun 2015 hingga 2019 mencatat total aset yang secara berturut-turut mencapai Rp2.3 triliun pada tahun 2015, Rp2.9 triliun pada tahun 2016, Rp4.3 triliun pada tahun 2017, Rp5.3 triliun pada tahun 2018, dan Rp6.3 triliun pada tahun 2019. Terdapat peningkatan atas total aset perusahaan yang disebabkan oleh adanya peningkatan aset lancar pada akun piutang usaha, persediaan, tagihan bruto kepada pemberi kerja, dan pajak dibayar di muka. Selain itu, peningkatan total aset pun disebabkan oleh peningkatan jumlah aset tidak lancar berupa investasi properti, piutang sewa proyek konsesi, uang muka proyek, penambahan penyertaan pada entitas asosiasi, dan sebagainya.

Selanjutnya, PT Brantas Abipraya (Persero) mencatat adanya laba bersih secara berturut-turut sebesar Rp131.6 miliar pada tahun 2015, Rp178.3 miliar pada tahun 2016, Rp271.3 miliar pada tahun 2017, Rp357.4 miliar pada tahun 2018, dan Rp282.6 miliar pada tahun 2019. Penurunan laba bersih pada tahun 2019 sebesar 20.91\% disebabkan oleh adanya penurunan pendapatan usaha perusahaan karena adanya penurunan pendapatan dari jasa konstruksi dan penurunan produksi per segmen yang diakibatkan oleh perolehan kontrak proyek baru yang tidak tercapai karena adanya pengunduran pelaksanaan tender proyek.

\section{b. $\quad$ PT Jasa Marga (Persero) Tbk.}

PT Jasa Marga (Persero) Tbk mencatat total aset perusahaan yang terus mengalami peningkatan menjadi sebesar Rp36.7 triliun pada tahun 2015, Rp53.5 triliun pada tahun 2016, Rp79.2 triliun pada tahun 2017, Rp82.4 triliun pada tahun 2018, dan Rp99.7 triliun pada tahun 2019. Peningkatan total aset perusahaan terutama disebabkan oleh adanya peningkatan aset lancar pada akun piutang lain-lain, persediaan, kas dan setara kas, serta pajak dibayar di muka. Selain itu, peningkatan total aset pun disebabkan oleh adanya peningkatan jumlah aset tidak lancar, terutama properti investasi, aset tak berwujud dalam bentuk hak pengusahaan jalan tol baru, investasi pada entitas asosiasi dan ventura bersama, dan sebagainya.

Selanjutnya, PT Jasa Marga (Persero) Tbk pada tahun 2015 hingga 2019 mencatat perolehan laba bersih yang secara berturut-turut sebesar Rp1.3 triliun pada tahun 2015, Rp1.8 triliun pada tahun 2016, Rp2.1 triliun pada tahun 2017, Rp2 triliun pada tahun 2018, dan Rp2.1 triliun pada tahun 2019.

\section{c. PT Semen Indonesia (Persero) Tbk.}

PT Semen Indonesia (Persero) Tbk pada tahun 2015 sampai dengan 2019 mencatat total aset sebesar Rp38.2 triliun pada tahun 2015, Rp44.2 triliun pada tahun 2016, Rp49.1 triliun pada tahun 2017, Rp50.8 triliun pada tahun 2018, dan Rp79.8 triliun pada tahun 2019. Peningkatan atas total aset diantaranya disebabkan oleh adanya perubahan aset lancar pada akun kas dan setara kas, piutang usaha, persediaan, dan pajak dibayar di muka. Selain itu, perubahan pun terjadi pada jumlah aset tidak lancar berupa aset pajak tangguhan, aset tetap sebagai wujud peningkatan realisasi pembangunan fasilitas produksi baru, dan sebagainya.

Selanjutnya, PT Semen Indonesia (Persero) Tbk pada tahun 2015 hingga 2019 mencatat perolehan laba bersih yang secara berturut-turut sebesar Rp4.53 triliun pada tahun 2015, Rp4.54 triliun pada tahun 2016, Rp1.6 triliun pada tahun 2017, Rp3.1 triliun pada tahun 2018, dan Rp2.4 triliun pada tahun 2019. Penurunan laba bersih perusahaan pada tahun 2017 disebabkan oleh adanya peningkatan biaya produksi yang berdampak pada tertekannya harga hasil produksi, sementara penurunan laba bersih pada tahun 2019 terutama disebabkan oleh adanya peningkatan beban keuangan perusahaan selama proses akuisisi PT Solusi Bangun Indonesia Tbk.

\subsection{Pelaksanaan Program Kemitraan dan Bina Lingkungan \\ a. $\quad$ PT Brantas Abipraya (Persero) \\ Berdasarkan laporan tahunan PKBL PT Brantas} Abipraya (Persero) yang diterbitkan pada tahun 2015 hingga 2019, pelaksanaan program PKBL dilakukan dengan total sumber dana yang 27 tersedia untuk disalurkan sebesar Rp2.8 miliar pada tahun 2015, Rp4.7 miliar pada tahun 2016, Rp5.6 miliar pada tahun 2017, Rp5.4 miliar pada tahun 2018, dan Rp4.2 miliar pada tahun 2019.

Porsi alokasi penyisihan laba bersih perusahaan terhadap total dana PKBL untuk disalurkan sepanjang tahun 2015-2019 secara berturut-turut adalah sebesar $64.15 \%$ atau sejumlah Rp1.8 miliar pada tahun 2015, 39.89\% atau sejumlah Rp1.9 miliar pada tahun 2016, 17.77\% atau sejumlah Rp1 miliar pada tahun 2017, 4.64\% atau sejumlah Rp250 juta pada tahun 2018, dan 0\% atau sejumlah Rp0 pada tahun 2019.

\section{b. $\quad$ PT Jasa Marga (Persero) Tbk.}

Berdasarkan informasi yang bersumber dari laporan PKBL PT Jasa Marga (Persero) Tbk, pelaksanaan program kemitraan dan bina lingkungan pada tahun 2015 hingga 2019 dilaksanakan dengan total dana yang 
tersedia untuk disalurkan sebesar Rp86.8 miliar pada tahun 2015, Rp89.6 miliar pada tahun 2016, Rp82.4 miliar pada tahun 2017, Rp67.6 miliar pada tahun 2018, dan Rp59.3 miliar pada tahun 2019.

Porsi alokasi penyisihan laba bersih perusahaan terhadap total dana tersedia untuk digunakan dalam penyaluran PKBL sepanjang tahun 2015-2019 adalah berturut-turut $0.57 \%$ atau sejumlah Rp495 juta pada tahun 2015, 11.61\% atau sejumlah Rp10.4 miliar pada tahun 2016, 15.35\% atau sejumlah Rp12.6 miliar pada tahun 2017, 10.35\% atau sejumlah Rp7 miliar pada tahun 2018, dan 0\% atau sejumlah Rp0 pada tahun 2019. Meskipun pada tahun 2019 tidak terdapat penyisihan laba untuk unit PKBL, pelaksanaan program bina lingkungan perusahaan tetap berjalan dengan biaya yang langsung dibebankan kepada laba bersih perusahaan dan tercatat dalam laporan keuangan tahun 2019, yaitu sebesar Rp29.2 miliar.

\section{c. PT Semen Indonesia (Persero) Tbk.}

Berdasarkan laporan tahunan PKBL yang diterbitkan oleh perusahaan pada tahun 2015 hingga 2019, total sumber dana yang tersedia untuk disalurkan dalam program kemitraan dan bina lingkungan PT Semen Indonesia (Persero) Tbk periode tahun 2015-2019 adalah sebesar Rp83.4 miliar pada tahun 2015, Rp171.3 miliar pada tahun 2016, Rp173 miliar pada tahun 2017, Rp113.5 miliar pada tahun 2018, dan Rp71.7 miliar pada tahun 2019.

Porsi alokasi penyisihan laba bersih perusahaan terhadap total dana PKBL untuk disalurkan sepanjang tahun 2015-2019 adalah berturut-turut 0\% atau sejumlah Rp0 pada tahun 2015, 46.82\% atau sejumlah Rp80.2 miliar pada tahun 2016, 34.90\% atau sejumlah Rp60.4 miliar pada tahun 2017, 0\% atau sejumlah Rp0 pada tahun 2018 dan 2019.

\subsection{Hubungan Kinerja Keuangan Terhadap Pelaksanaan Program Kemitraan}

a. $\quad$ PT Brantas Abipraya (Persero)

Tabel 1 ROA dan RPD-PK PT Brantas Abipraya, Tahun 2015-2019

\begin{tabular}{|l|l|l|}
\hline \multirow{2}{*}{ TAHUN } & \multirow{2}{*}{ ROA } & $\begin{array}{c}\text { RASIO } \\
\text { PENYALURAN } \\
\text { DANA }\end{array}$ \\
\cline { 3 - 3 } & & \multicolumn{2}{|c|}{ PK } \\
\hline 2015 & $5.78 \%$ & $0.11 \%$ \\
\hline 2016 & $5.99 \%$ & $1.10 \%$ \\
\hline 2017 & $6.28 \%$ & $1.58 \%$ \\
\hline 2018 & $6.74 \%$ & $1.47 \%$ \\
\hline 2019 & $4.48 \%$ & $1.44 \%$ \\
\hline
\end{tabular}

Sumber: Laporan Keuangan dan Laporan PKBL tahun 2015-2020 (data diolah)
Return on asset PT Brantas Abipraya tahun 2015-2019 cenderung stabil pada kisaran 5.85\% meskipun sempat mengalami penurunan pada tahun 2019 yang diakibatkan oleh adanya penurunan laba bersih perusahaan sebesar $20.91 \%$ dan peningkatan total aset perusahaan sebesar $18.85 \%$. Rasio penyaluran dana program kemitraan PT Brantas Abipraya (Persero) pun cukup stabil meskipun sempat memiliki rasio yang rendah pada tahun 2015 karena total penyaluran dananya yang rendah.

b. $\quad$ PT Jasa Marga (Persero) Tbk.

Tabel 2 ROA dan RPD-PK PT Jasa Marga,

Tahun 2015-2019

\begin{tabular}{|c|l|l|}
\hline TAHUN & ROA & $\begin{array}{c}\text { RASIO } \\
\text { PENYALURA } \\
\text { N DANA }\end{array}$ \\
\cline { 3 - 3 } & & PK \\
\hline 2015 & $3.59 \%$ & $1.19 \%$ \\
\hline 2016 & $3.37 \%$ & $0.97 \%$ \\
\hline 2017 & $2.64 \%$ & $2.56 \%$ \\
\hline 2018 & $2.47 \%$ & $2.71 \%$ \\
\hline 2019 & $2.08 \%$ & $2.66 \%$ \\
\hline
\end{tabular}

Sumber: Laporan Keuangan dan Laporan PKBL tahun 2015-2020 (data diolah)

Return on asset PT Jasa Marga pada tahun 2015-2019 memiliki tren penurunan yang disebabkan oleh total aset perusahaan yang terus meningkat secara signifikan sementara laba bersih perusahaan mengalami peningkatan yang tidak setinggi peningkatan total aset perusahaan. Rasio penyaluran dana PT Jasa Marga tahun 2015- 2019 cenderung fluktuatif dengan peningkatan terbesar terjadi pada tahun 2017 sebesar 165.34\%, yaitu dari 0.97\% pada tahun 2016 menjadi 2.56\% pada tahun 2017. Hal ini disebabkan oleh adanya peningkatan atas laba bersih sebesar $16.12 \%$ dan peningkatan atas jumlah dana yang disalurkan sebesar $208.10 \%$.

c. PT Semen Indonesia (Persero) Tbk.

Tabel 3 ROA dan RPD-PK PT Semen Indonesia,

Tahun 2015-2019

\begin{tabular}{|c|c|c|}
\hline TAHUN & ROA & $\begin{array}{c}\text { RASIO } \\
\text { PENYALURAN } \\
\text { DANA }\end{array}$ \\
\cline { 3 - 3 } & & \begin{tabular}{c} 
PK \\
\cline { 3 - 3 }
\end{tabular} \\
\hline 2015 & $11.86 \%$ & $1.52 \%$ \\
\hline 2016 & $10.25 \%$ & $1.74 \%$ \\
\hline 2017 & $3.36 \%$ & $4.70 \%$ \\
\hline 2018 & $6.08 \%$ & $2.51 \%$ \\
\hline 2019 & $2.97 \%$ & $0.01 \%$ \\
\hline
\end{tabular}

Sumber: Laporan Keuangan dan Laporan PKBL tahun 2015-2020 (data diolah) 
Tingkat return on asset PT Semen Indonesia (Persero) Tbk periode tahun 2015-2019 mengalami fluktuasi dan cenderung kurang stabil. Rasio penyaluran dana program kemitraan PT Semen Indonesia (Persero) Tbk. periode tahun 2015-2019 mengalami fluktuasi dengan tingkat terendah rasio penyaluran dana terjadi pada tahun 2019 sebesar $0.01 \%$ yang disebabkan oleh total penyaluran dana program kemitraan yang menurun menjadi Rp326 juta dari Rp77.5 miliar pada tahun 2018. Penurunan terjadi karena pada tahun 2019, PT Semen Indonesia (Persero) Tbk melakukan pengalihan penyaluran dana program kemitraan kepada BUMN Khusus PT Permodalan Nasional Madani (Persero) dengan mekanisme hibah sebesar Rp5 miliar.

\section{d. Rata-Rata Perusahaan Objek Penulisan}

Berdasarkan hasil perhitungan yang telah tertulis dalam pembahasan sebelumnya, tidak ditemukan adanya persamaan pola peningkatan dan penurunan yang terjadi pada kedua rasio yang diperhitungkan, yaitu return on asset dan rasio penyaluran dana program kemitraan.

Tabel 4 ROA dan RPD-PK Rata-Rata, Tahun 2015-2019

\begin{tabular}{|c|l|l|}
\hline TAHUN & \multirow{2}{*}{ ROA } & $\begin{array}{c}\text { RASIO } \\
\text { PENYALURA } \\
\text { N DANA }\end{array}$ \\
\cline { 3 - 3 } & & \multicolumn{2}{|c|}{ PK } \\
\hline 2015 & $7.08 \%$ & $0.94 \%$ \\
\hline 2016 & $6.54 \%$ & $1.27 \%$ \\
\hline 2017 & $4.10 \%$ & $2.95 \%$ \\
\hline 2018 & $5.10 \%$ & $2.23 \%$ \\
\hline 2019 & $3.18 \%$ & $1.37 \%$ \\
\hline
\end{tabular}

Sumber: Laporan Keuangan dan Laporan PKBL tahun 2015-2020 (data diolah)

Hasil yang diperoleh berdasarkan tinjauan diatas memiliki hasil yang sama dengan hasil penelitian oleh (Septiana \& Nur DP, 2012), yang menyimpulkan bahwa biaya kemitraan, atau dana penyelenggaraan program kemitraan yang disalurkan, tidak memiliki pengaruh dan tidak signifikan terhadap kinerja keuangan perusahaan.

4.4. Hubungan Kinerja Keuangan Terhadap Pelaksanaan Program Bina Lingkungan

a. PT Brantas Abipraya (Persero)

Tabel 5 ROA dan RPD-BL PT Brantas Abipraya, Tahun 2015-2019

\begin{tabular}{|l|c|c|}
\hline TAHUN & ROA & $\begin{array}{c}\text { RASIO } \\
\text { PENYALUR } \\
\text { AN DANA }\end{array}$ \\
\cline { 3 - 3 } & & BL \\
\hline 2015 & $5.78 \%$ & $0.79 \%$ \\
\hline
\end{tabular}

\begin{tabular}{|l|l|l|}
\hline 2016 & $5.99 \%$ & $0.94 \%$ \\
\hline 2017 & $6.28 \%$ & $1.91 \%$ \\
\hline 2018 & $6.74 \%$ & $0.001 \%$ \\
\hline 2019 & $4.48 \%$ & $0.00 \%$ \\
\hline
\end{tabular}

Sumber: Laporan Keuangan dan Laporan PKBL tahun 2015-2020 (data diolah)

Rasio penyaluran dana program bina lingkungan yang diselenggarakan oleh PT Brantas Abipraya pada periode tahun 2015-2019 mengalami fluktuasi dengan penurunan rasio penyaluran dana yang signifikan, mencapai sebesar $99.96 \%$ pada tahun 2018 dan $100 \%$ pada tahun 2019.

Penurunan pada tahun 2018 terjadi karena adanya penurunan jumlah dana yang disalurkan dalam program bina lingkungan PT Brantas Abipraya pada tahun 2018, yang semula berjumlah Rp5.2 miliar pada tahun 2017 menjadi Rp2.4 juta pada tahun 2018. Kemudian, pada tahun 2019 perusahaan tidak menyalurkan dana program bina lingkungan sehingga rasio penyaluran dananya adalah $0 \%$.

b. $\quad$ PT Jasa Marga (Persero) Tbk.

Tabel 6 ROA dan RPD-BL PT Jasa Marga,

Tahun 2015-2019

\begin{tabular}{|c|c|c|}
\hline \multirow{2}{*}{ TAHUN } & ROA & $\begin{array}{c}\text { RASIO } \\
\text { PENYALURAN } \\
\text { DANA }\end{array}$ \\
\cline { 3 - 3 } & & BL \\
\hline 2015 & $3.59 \%$ & $0.68 \%$ \\
\hline 2016 & $3.37 \%$ & $0.95 \%$ \\
\hline 2017 & $2.64 \%$ & $1.01 \%$ \\
\hline 2018 & $2.47 \%$ & $1.73 \%$ \\
\hline 2019 & $2.08 \%$ & $1.41 \%$ \\
\hline
\end{tabular}

Sumber: Laporan Keuangan dan Laporan PKBL tahun 2015-2020 (data diolah)

Rasio penyaluran dana program bina lingkungan yang diselenggarakan oleh PT Jasa Marga pada periode tahun 2015-2019 memiliki kecenderungan untuk meningkat meskipun sempat mengalami penurunan rasio penyaluran dana pada tahun 2019.

Terdapat kebijakan baru yang diterbitkan pada bulan Maret 2018 terkait pencatatan penyaluran dana program bina lingkungan yang diterapkan di PT Jasa Marga. Pencatatan atas penyaluran dana bina lingkungan yang dibebankan pada perusahaan dilakukan dalam laporan keuangan perusahaan sehingga data PKBL untuk tahun 2018 dan 2019 diperoleh dari laporan keuangan PT Jasa Marga tahun 2018 dan 2019 serta laporan PKBL PT Jasa Marga tahun 2018, karena saldo kas untuk program bina lingkungan dari tahun 2017 masih dapat digunakan untuk penyelenggaraan program bina lingkungan pada tahun 2018.

c. PT Semen Indonesia (Persero) Tbk.

Halaman 54 
Tabel 7 ROA dan RPD-BL PT Semen Indonesia, Tahun 2015-2019

\begin{tabular}{|c|l|l|}
\hline TAHUN & ROA & $\begin{array}{c}\text { RASIO } \\
\text { PENYALURAN } \\
\text { DANA }\end{array}$ \\
\cline { 3 - 3 } & & BL \\
\hline 2015 & $11.86 \%$ & $0.001 \%$ \\
\hline 2016 & $10.25 \%$ & $1.26 \%$ \\
\hline 2017 & $3.36 \%$ & $3.58 \%$ \\
\hline 2018 & $6.08 \%$ & $0.77 \%$ \\
\hline 2019 & $2.97 \%$ & $0.32 \%$ \\
\hline
\end{tabular}

Sumber: Laporan Keuangan dan Laporan PKBL tahun 2015-2020 (data diolah)

Rasio penyaluran dana bina lingkungan PT Semen Indonesia pada tahun 2015-2019 cenderung fluktuatif dengan titik terendah rasio penyaluran dana program bina lingkungan PT Semen Indonesia (Persero) Tbk terjadi pada tahun 2015 sebesar $0.001 \%$, dengan jumlah dana program bina lingkungan yang disalurkan adalah sebesar Rp30 juta sebelum kemudian meningkat menjadi Rp57 miliar pada tahun 2016.

\section{d. Rata-Rata Perusahaan Objek Penulisan}

Berdasarkan hasil perhitungan yang telah diuraikan dalam pembahasan sebelumnya, tidak ditemukan adanya persamaan pola peningkatan dan penurunan yang terjadi pada kedua rasio yang diperhitungkan, yaitu return on asset dan rasio penyaluran dana program bina lingkungan.

Tabel 8 ROA dan RPD-BL Rata-Rata,

Tahun 2015-2019

\begin{tabular}{|c|c|c|}
\hline \multirow{2}{*}{ TAHUN } & ROA & $\begin{array}{c}\text { RASIO } \\
\text { PENYALURAN } \\
\text { DANA }\end{array}$ \\
\cline { 3 - 3 } & & BL \\
\hline 2015 & $7.08 \%$ & $0.49 \%$ \\
\hline 2016 & $6.54 \%$ & $1.05 \%$ \\
\hline 2017 & $4.10 \%$ & $2.17 \%$ \\
\hline 2018 & $5.10 \%$ & $0.83 \%$ \\
\hline 2019 & $3.18 \%$ & $0.58 \%$ \\
\hline
\end{tabular}

Sumber: Laporan Keuangan dan Laporan PKBL tahun 2015-2020 (data diolah)

Hasil yang menyatakan bahwa tidak terdapat hubungan antara kinerja keuangan dengan penyaluran dana bina lingkungan ini memiliki hasil yang sama dengan yang dihasilkan dari penelitian oleh (Fitriani, 2013), yang menyatakan bahwa biaya lingkungan, atau biaya penyelenggaraan program bina lingkungan pada BUMN, tidak berpengaruh terhadap kinerja keuangan perusahaan. Dalam studi tersebut, diuraikan lebih lanjut mengenai penyebab ketiadaan hubungan antara kinerja keuangan dan penyaluran dana program bina lingkungan, yaitu karena pelaksanaan tanggung jawab sosial yang diselenggarakan melalui adanya pembebanan biaya sosial (social cost) akan cenderung dilakukan dengan tujuan atau perspektif manajemen, sehingga penyaluran dananya cenderung bersifat derma atau charity dan kurang memperhatikan kebutuhan masyarakat selaku stakeholder.

\section{KESIMPULAN DAN SARAN}

\subsection{Kesimpulan}

Dari hasil penelitian dan pembahasan di atas, dapat dikemukakan simpulan sebagai berikut:

1. Rasio profitabilitas berupa return on asset rata-rata perusahaan objek pada tahun 2015 hingga 2019 secara berturut-turut adalah sebesar 7.08\%, $6.54 \%, 4.10 \%, 5.10 \%$, dam $3.18 \%$. Rata-rata return on asset perusahaan objek penulisan bersifat fluktuatif dan memiliki kecenderungan untuk mengalami penurunan.

2. Rasio penyaluran dana program kemitraan dan program bina lingkungan rata-rata perusahaan objek pada tahun 2015-2019 cenderung stabil meskipun terdapat fluktuasi. Fluktuasi pada rasio penyaluran dana disebabkan oleh adanya perubahan pada jumlah penyaluran dana, laba bersih perusahaan, dan/atau kebijakan yang berlaku dalam pelaksanaan program kemitraan dan bina lingkungan pada periode penyaluran.

3. Kinerja keuangan dan penyaluran dana program kemitraan dan program bina lingkungan tidak berhubungan.

\section{IMPLIKASI DAN KETERBATASAN}

Program Kemitraan dan Bina Lingkungan merupakan salah satu program tanggung jawab sosial BUMN yang bermanfaat banyak bagi masyarakat, terutama masyarakat yang berlokasi di sekitar wilayah perusahaan beroperasi. Selain itu, program kemitraan dan bina lingkungan, sesuai tujuan awal munculnya gagasan tanggung jawab sosial, dapat berpartisipasi dalam mewujudkan pembangunan yang berkelanjutan. Hasil penelitian ini menunjukkan bahwa meskipun banyak bermanfaat, pelaksanaan PKBL belum dilakukan secara optimal, dan masih memiliki ruang untuk pengembangan kedepannya agar manfaat yang diperoleh, baik itu oleh masyarakat sekitar maupun masyarakat luas, dapat lebih maksimal.

Meskipun begitu, perlu digarisbawahi bahwa penelitian ini dilakukan pada 3 (tiga) perusahaan objek penelitian dengan menggunakan analisis rasio, menunjukkan adanya kemungkinan bahwa data yang digunakan kurang mampu untuk menggambarkan keadaan yang sebenarnya sehingga dapat mempengaruhi keandalan kesimpulan yang dihasilkan dan penelitian lebih lanjut oleh peneliti selanjutnya mungkin akan diperlukan. Selain itu, rasio kinerja keuangan yang digunakan dalam penelitian hanya return on asset, sehingga bagi peneliti selanjutnya, 
PENYALURAN DANA PROGRAM KEMITRAAN DAN BINA LINGKUNGAN (PKBL) DAN KINERJA KEUANGAN BUMN

Rahmaditha Dewisari ${ }^{1}$ dan Roby Syaiful Ubed $^{2}$

disarankan agar dapat turut menggunakan rasio-rasio atau variabel lainnya yang mampu menentukan hubungan antara penyaluran dana PKBL dengan kinerja keuangan perusahaan.

\section{DAFTAR PUSTAKA}

Anatan, L. (2009). CORPORATE SOCIAL RESPONSIBILITY (CSR): Tinjauan Teoritis dan Praktik di Indonesia . Jurnal Manajemen Maranatha, 6677.

Dewi, N. A., Endiana, I. M., \& Arizona, I. E. (2019). PENGARUH RASIO LIKUIDITAS, RASIO LEVERAGE DAN RASIO PROFITABILITAS TERHADAP FINANCIAL DISTRESS PADA PERUSAHAAN MANUFAKTUR. KHARISMA, 322-333.

Fitriani, A. (2013). Pengaruh Kinerja Lingkungan dan Biaya Lingkungan terhadap Kinerja Keuangan pada BUMN. Jurnal IImu Manajemen, Volume 1 Nomor 1, 137-148.

Hermuningsih, S. (2012). Pengaruh Profitabilitas, Size Terhadap Nilai Perusahaan Dengan Struktur Modal Sebagai Variabel Intervening. Jurnal Siasat Bisnis 16(2), 232-242.

Marnelly, T. (2012). Corporate Social Responsibility (CSR): Tinjauan Teori dan Praktek di Indonesia. Jurnal Aplikasi Bisnis, 49-59.

Mirzaqon, A. (2018). STUDI KEPUSTAKAAN MENGENAI LANDASAN TEORI DAN PRAKTIK KONSELING EXPRESSIVE WRITING. Jurnal BK UNESA.

Pemerintah Republik Indonesia. (2003). UndangUndang nomor 17 tahun 2003 tentang Keuangan Negara. Jakarta: Presiden Republik Indonesia.

Pemerintah Republik Indonesia. (2003). UndangUndang Nomor 19 tahun 2003 tentang Badan Usaha Milik Negara. Jakarta: Presiden Republik Indonesia.

Pemerintah Republik Indonesia. (2005). Peraturan Pemerintah Nomor 44 tahun 2005 tentang Tata Cara Penyertaan dan Penatausahaan Modal Negara. Jakarta, Indonesia: Presiden Republik Indonesia.

Pemerintah Republik Indonesia. (2015). Peraturan Menteri Badan Usaha Milik Negara nomor PER-09/MBU/07/2015 tentang Program Kemitraan dan Program Bina Lingkungan Badan Usaha Milik Negara. Jakarta: Menteri Badan Usaha Milik Negara.

Pemerintah Republik Indonesia. (2016). Peraturan Pemerintah nomor 72 tahun 2016 tentang
Perubahan atas Peraturan Pemerintah Nomor 44 tahun 2005 tentang Tata Cara Penyertaan dan Penatausahaan Modal Negara pada Badan Usaha Milik Negara dan Perseroan Terbatas. Jakarta: Presiden Republik Indonesia.

Pemerintah Republik Indonesia. (2017). Peraturan Menteri Badan Usaha Milik Negara nomor PER-02/MBU/07/2017 tentang Perubahan Kedua atas Peraturan Menteri Badan Usaha Milik Negara nomor PER09/MBU/07/2015 tentang Program Kemitraan dan Program Bina Lingkungan Badan Usaha Milik Negara. Jakarta: Menteri Badan Usaha Milik Negara.

Pemerintah Republik Indonesia. (2020). Peraturan Menteri Badan Usaha Milik Negara nomor PER-02/MBU/04/2020 tentang Perubahan Ketiga atas Peraturan Menteri Badan Usaha Milik Negara nomor PER- 64 09/MBU/07/2015 tentang Program Kemitraan dan Program Bina Lingkungan Badan Usaha Milik Negara. Jakarta: Menteri Badan Usaha Milik Negara.

Pratt, S. P., \& Niculita, A. V. (2008). Valuing a Business: The Analysis and Appraisal of Closely Held Companies, Fifth Edition. New York: Shanon Pratt Valuation Inc., Copyright by The McGraw Hill Companies.

Priyadi, M. P., \& Chumaidah. (2018). PENGARUH PROFITABILITAS DAN SIZE TERHADAP NILAI PERUSAHAAN DENGAN CSR SEBAGAI VARIABEL PEMODERASI. Jurnal Ilmu dan Riset Akuntansi 7(3).

Purwanto, A. (2011). PENGARUH TIPE INDUSTRI, UKURAN PERUSAHAAN, PROFITABILITAS, TERHADAP CORPORATE SOCIAL RESPONSIBILITY. JURNAL AKUNTANSI DAN AUDITING, 8(1), 12-29. https://doi.org/10.14710/jaa.8.1.12-29.

Septiana, R. A., \& Nur DP, E. (2012). Pengaruh Implementasi Corporate Social Responsibility terhadap Profitabilitas Perusahaan (Studi pada Perusahaan Manufaktur yang Listing di BEI 2007 s.d. 2009). Jurnal Pendidikan Ekonomi dan Bisnis, vol.4, no.02, 71-84.

Tanudjaja, B. B. (2008). PERKEMBANGAN CORPORATE SOCIAL RESPONSIBILITY DI INDONESIA. Nirmana, 92-98.

Zed, M. (2004). Metode Peneletian Kepustakaan. Jakarta: Yayasan Obor Indonesia.

ILUSTRASI TABEL 
Tabel 9. Ikhtisar Laporan Keuangan PT Brantas Abipraya (Persero) tahun 2015-2019

\begin{tabular}{|l|r|r|r|r|r|}
\hline \multicolumn{5}{|c|}{ IKHTISAR Laporan Keuangan tahun 2015-2019 (dalam juta rupiah) } \\
\hline & \multicolumn{1}{|c|}{2015} & \multicolumn{1}{c|}{2016} & \multicolumn{1}{c|}{2017} & \multicolumn{1}{c|}{2018} & 2019 \\
\hline Aset Lancar & $1,500,180.44$ & $1,869,064.75$ & $2,974,822.64$ & $3,195,198.04$ & $3,888,979.78$ \\
\hline Aset Tidak Lancar & $778,613.07$ & $1,107,300.76$ & $1,341,600.73$ & $2,108,467.96$ & $2,414,256.82$ \\
\hline TOTAL ASET & $2,278,793.51$ & $2,976,365.51$ & $4,316,423.37$ & $5,303,665.99$ & $6,303,236.60$ \\
\hline Liabilitas Jangka Pendek & $1,081,661.03$ & $1,634,319.06$ & $2,366,197.16$ & $2,469,145.84$ & $3,089,041.33$ \\
\hline Liabilitas Jangka Panjang & $525,512.02$ & $510,706.69$ & $893,462.01$ & $1,259,286.12$ & $1,392,876.64$ \\
\hline TOTAL LIABILITAS & $1,607,173.06$ & $2,145,025.76$ & $3,259,659.16$ & $3,728,431.95$ & $4,481,917.97$ \\
\hline Ekuitas & $671,620.45$ & $831,339.75$ & $1,056,764.21$ & $1,575,234.04$ & $1,821,318.63$ \\
\hline TOTAL LIABILITAS DAN EKUITAS & $2,278,393.51$ & $2,976,365.51$ & $4,316,423.37$ & $5,303,665.99$ & $6,303,236.60$ \\
\hline TOTAL PENDAPATAN & $3,110,311.35$ & $3,323,325.77$ & $3,885,472.26$ & $4,729,278.07$ & $3,636,436.59$ \\
\hline LABA BRUTO & $396,589.13$ & $492,087.33$ & $657,995.46$ & $724,006.41$ & $620,475.89$ \\
\hline EBIT & $219,122.82$ & $271,289.37$ & $381,178.79$ & $359,505.91$ & $283,264.24$ \\
\hline LABA BERSIH & $131,605.80$ & $178,254.38$ & $271,273.04$ & $357,359.07$ & $282,624.82$ \\
\hline
\end{tabular}

Sumber: Laporan Keuangan PT Brantas Abipraya (Persero) tahun 2015-2019

Tabel 10 Ikhtisar Laporan Keuangan PT Jasa Marga (Persero) Tbk tahun 2015-2019

\begin{tabular}{|l|c|c|c|c|c|}
\hline \multicolumn{5}{|c|}{ IKHTISAR Laporan Keuangan tahun $2015-2019$ (dalam juta rupiah) } \\
\hline & 2015 & 2016 & 2017 & 2018 & 2019 \\
\hline Aset Lancar & $3,729,046.50$ & $12,965,884.49$ & $18,987,065.06$ & $11,629,996.00$ & $11,612,566.00$ \\
\hline Aset Tidak Lancar & $32,995,935.98$ & $40,534,438.17$ & $60,205,707.73$ & $70,788,607.00$ & $88,067,004.00$ \\
\hline TOTAL ASET & $36,724,982.49$ & $53,500,322.66$ & $79,192,772.79$ & $82,418,603.00$ & $99,679,570.00$ \\
\hline Liabilitas Jangka Pendek & $7,543,411.36$ & $18,626,988.99$ & $24,997,940.29$ & $31,081,475.00$ & $41,526,417.00$ \\
\hline Liabilitas Jangka Panjang & $16,812,906.66$ & $18,534,493.59$ & $35,835,392.97$ & $31,138,139.00$ & $34,967,416.00$ \\
\hline TOTAL LIABILITAS & $24,356,318.02$ & $37,161,482.59$ & $60,833,333.27$ & $62,219,614.00$ & $76,493,833.00$ \\
\hline Ekuitas & $12,368,664.47$ & $16,338,840.06$ & $18,359,439.52$ & $20,198,989.00$ & $23,185,737.00$ \\
\hline TOTAL LIABILITAS DAN EKUITAS & $36,724,982.49$ & $53,500,322.66$ & $79,192,772.79$ & $81,418,603.00$ & $99,679,570.00$ \\
\hline TOTAL PENDAPATAN & $9,848,242.05$ & $16,661,402.99$ & $35,092,196.19$ & $36,974,075.00$ & $26,345,260.00$ \\
\hline LABA BRUTO & $4,127,819.96$ & $4,856,391.32$ & $5,307,886.82$ & $5,917,510.00$ & $6,444,643.00$ \\
\hline EBIT & $2,068,304.23$ & $2,649,679.25$ & $3,250,452.46$ & $3,210,309.00$ & $3,097,603.00$ \\
\hline LABA BERSIH & $1,319,200.55$ & $1,803,054.46$ & $2,093,656.06$ & $2,036,493.00$ & $2,073,888.00$ \\
\hline
\end{tabular}

Sumber: Laporan Keuangan PT Jasa Marga (Persero) Tbk. tahun 2015-2019

Tabel 11 Ikhtisar Laporan Keuangan PT Semen Indonesia (Persero) Tbk tahun 2015-2019

\begin{tabular}{|l|c|c|c|c|c|}
\hline \multicolumn{5}{|c|}{ IKHTISAR Laporan Keuangan tahun 2015-2019 (dalam juta rupiah) } \\
\hline & 2015 & 2016 & 2017 & 2018 & 2019 \\
\hline Aset Lancar & $10,538,703.91$ & $10,373,158.83$ & $13,801,818.53$ & $16,091,024.00$ & $16,658,531.00$ \\
\hline Aset Tidak Lancar & $27,614,415.02$ & $33,853,737,15$ & $35,266,831.68$ & $34,692,812.00$ & $63,148,536.00$ \\
\hline TOTAL ASET & $38,153,118.93$ & $44,226,895.98$ & $49,068,650.21$ & $50,783,836.00$ & $79,807,067.00$ \\
\hline Liabilitas Jangka Pendek & $6,599,189.62$ & $8,151,673.43$ & $8,803,577.05$ & $8,179,819.00$ & $12,240,252.00$ \\
\hline Liabilitas Jangka Panjang & $4,113,130.91$ & $5,500,831.09$ & $10,219,040.52$ & $9,988,702.00$ & $31,674,891.00$ \\
\hline TOTAL LIABILITAS & $10,712,320.53$ & $13,652,504.52$ & $19,022,617.57$ & $18,168,521.00$ & $43,915,143.00$ \\
\hline Ekuitas & $27,440,798.40$ & $30,574,391.46$ & $30,046,032.64$ & $32,615,315.00$ & $33,891,924.00$ \\
\hline TOTAL LIABILITAS DAN EKUITAS & $38,153,118.93$ & $44,226,895.98$ & $49,068,650.21$ & $50,783,836.00$ & $79,807,067.00$ \\
\hline TOTAL PENDAPATAN & $26,948,004.47$ & $26,134,306.14$ & $27,813,664.18$ & $30,687,626.00$ & $40,368,107.00$ \\
\hline LABA BRUTO & $10,645,996.37$ & $9,855,872.45$ & $7,959,598.77$ & $9,330,530.00$ & $12,713,983.00$ \\
\hline EBIT & $5,850,923.49$ & $5,084,621.54$ & $2,253,893.32$ & $4,104,959.00$ & $3,195,775.00$ \\
\hline LABA BERSIH & $4,525,441.04$ & $4,535,036.82$ & $1,650,006.25$ & $3,085,704.00$ & $2,371,233.00$ \\
\hline
\end{tabular}

Sumber: Laporan Keuangan PT Semen Indonesia (Persero) Tbk. tahun 2015-2019/ 